\title{
PREVALENSI HIPERURISEMIA PADA REMAJA OBESE DI SMA KRISTEN TUMOU TOU KOTA BITUNG
}

\author{
${ }^{1}$ Olivia C. Mulalinda \\ ${ }^{2}$ Aaltje Manampiring \\ ${ }^{2}$ Fatimawali
}

\author{
${ }^{1}$ Kandidat Skripsi Fakultas Kedokteran Universitas Sam Ratulangi Manado \\ ${ }^{2}$ Bagian Kimia Fakultas Kedokteran Universitas Sam Ratulangi Manado \\ Email: olivc_16@yahoo.co.id
}

\begin{abstract}
Abstrak: Hiperurisemia adalah keadaan kadar asam urat dalam darah yang meningkat di atas normal.Pada laki-laki lebih dari 7,0 mg/dL dan lebih dari 6,0 mg/dL pada perempuan. Hiperurisemia bisa terjadi karena peningkatan metabolisme asam urat, penurunan pengeluaran asam urat atau gabungan keduanya. Obesitas merupakan salah satu faktor resiko terjadinya hiperurisemia. Sesuai kriteria International Diabetes federation (IDF) dikategorikan obesitas jika nilai lingkar pinggang $\geq 90 \mathrm{~cm}$ pada laki -laki dan $\geq 80 \mathrm{~cm}$ pada perempua n. Penelitian ini bertujuan untuk mengetahui prevalensi hiperurisemia pada remaja/siswa obese di SMA Kristen Tumou Tou Kota Bitung. Penelitian dilakukan menggunakan metode observasional dengan desain crossectional study, dimana obesitas diukur berdasarkan lingkar pinggang dan kadar asam urat diperiksa di laboratorium. Berdasarkan hasil pemeriksaan lingkar pinggang pada 137 populasi didapatkan 17 siswa termasuk dalam kategori obesitas dan dari ke 17 siswa tersebut hanya 11 siswa yang bersedia untuk melakukan pemeriksaan kadar asam urat. Dari hasil pemeriksaan tersebut didapatkan 4 siswa obese yang memiliki kadar asam urat diatas normal, sehingga dapat disimpulkan prevalensi hiperurisemia pada remaja/siswa obese adalah 36,36\%.

Kata kunci: Hiperurisemia, Obesitas, Remaja, SMA Kristen Tumou Tou Kota Bitung.
\end{abstract}

\begin{abstract}
Hiperuricemia is condition where the uric acid level increases over. For man, the level is more than $7,0 \mathrm{mg} / \mathrm{dL}$ and $6,0 \mathrm{mg} / \mathrm{dL}$ for woman. It happens because of uric acid metabolism raising, reducting the uric acid secreation or both things. Obesity can be one of the risk factors hiperuricemia occurs. Based on the international diabetes federation (IDF) criteria, obesity is categorized if the value of waist measurement is $90 \mathrm{~cm}$ for man and $\geq 80 \mathrm{~cm} \mathrm{f}$ or woman.The research aims to know the hiperuricemia prevalences at obese adolescent/students in Tumou Tou Christian Senior High School Bitung City. This research uses observational method with crossectional study design, where obesity is measured based on waist measurement and uric acid level which is checked at the laboratorium. Based on waist examination result at 137 population, it is obtained 17 obese students. From those 17, there are 11 students do the uric acid examination. Based on the examination , there are 4 obese students who have over uric acid level, so it can be concluded that the hiperuricemia prevalence at obese adolecents/students is $36,36 \%$.
\end{abstract}

Keyword: Hiperuricemia, Obesity, Adolescents, Tumou Tou Christian Senior High School Bitung City.

Asam urat merupakan produk akhir dari metabolisme purin. ${ }^{1,2}$ Kadarnya dalam darah bervariasi menurut umur dan jenis kelamin. Nilai normal asam urat pada laki-laki di bawah $7 \mathrm{mg} / \mathrm{dL}$, sedangkan pada perempuan di bawah $6 \mathrm{mg} / \mathrm{dL}$. Organ yang bertanggung jawab dalam mengendalikan kadar asam urat didalam darah agar selalu dalam batas 
normal adalah ginjal. Ginjal mengatur pembuangan asam urat melalui urin. Namun bila produksi asam urat menjadi sangat berlebihan atau pembuangannya berkurang, akibatnya kadar asam urat dalam darah menjadi tinggi. Dan keadaan ini disebut hiperurisemia. $^{3}$

Hiperurisemia adalah keadaan kadar asam urat dalam darah yang meningkat di atas normal. Hiperurisemia bisa terjadi karena peningkatan metabolisme asam urat (overproduction), penurunan pengeluaran asam urat urin (underexcretion), atau gabungan keduanya. ${ }^{4}$

Prevalensi hiperurisemia di Indonesia masih belum diketahui pasti, umumnya merupakan angka penyakit gout. Beberapa bukti menyatakan bahwa hiperurisemia sering dijumpai di Sulawesi. Menurut penelitian terdahulu insiden hiperurisemia sering berkaitan dengan letak geografis, pola budaya masyarakat setempat, dimana yang bermukim di daerah pesisir pantai maupun didaerah dataran tinggi mempunyai kebiasaan pola makan protein maupun lemak tinggi, serta kebiasaan mengkonsumsi minuman beralkohol. ${ }^{3}$

Obesitas merupakan faktor resiko terjadinya hiperurisemia. ${ }^{1}$ Obesitas terjadi bila besar dan jumlah sel lemak bertambah pada tubuh seseorang. ${ }^{5}$ Lingkar pinggang merupakan salah satu pengukuran antopometri yang digunakan untuk mengukur obesitas. Sesuai kriteria International Diabetes Federation (IDF) dikategorikan obesitas jika nilai lingkar pinggang $\geq 90 \mathrm{~cm}$ pada laki-laki dan $\geq 80 \mathrm{~cm}$ pada perempuan. ${ }^{6}$

Genetik, gaya hidup dan faktor lingkungan berperan dominan pada banyak orang dengan obesitas. ${ }^{7}$ Gaya hidup dan pola makan masyarakat saat ini memicu timbulnya berbagai macam penyakit. Mengkonsumsi makanan yang berlemak, makan makanan cepat saji dan kurang berolahraga merupakan kebiasaan buruk masyarakat. $^{8}$

Saat ini diperkirakan jumlah orang di seluruh dunia dengan status gizi obesitas melebihi 250 juta orang, yaitu sekitar 7\% dari populasi orang dewasa. Menurut Center for Disease Control (CDC) tahun 2012, prevalensi obesitas telah mencapai lebih dari 72 juta jiwa dan mencakup 17\% populasi anak-anak. Di Amerika serikat dan di banyak negara maju lainnya prevalensi obesitas pada anak dan dewasa sangat meningkat, yang bertambah $\geq 30 \%$ selama dekade terakhir. ${ }^{7,9}$

Berdasarkan laporan hasil riset kesehatan dasar (RISKESDAS) tahun 2013 Sulawesi Utara menempati posisi kedua tertinggi setelah DKI yaitu sekitar 37\% prevalensi obesitas sentral penduduk umur $\geq 15$. $^{10}$

Di kota bitung sudah pernah dilakukan penelitian dengan menggunakan sampel remaja di SMA N 1 Bitung di dapati sebesar $42 \%$ prevalensi remaja obese dan sebesar $10 \%$ remaja obese yang mengalami hiperurisemia. $^{11}$ Oleh karena itu peneliti ingin melakukan penelitian untuk lebih mengetahui prevalensi hiperurisemia pada remaja obese di Kota Bitung dengan populasi yang berbeda dengan penelitian sebelumnya yaitu, di SMA Kristen Tumou Tou.

\section{METODE PENELITIAN}

Penelitian ini menggunakan metode observasional dengan desain crossectional study, dimana obesitas diukur berdasarkan lingkar pinggang dan kadar asam urat diperiksa di laboratorium. Waktu penelitian dilakukan pada bulan November Desember 2013. Sampel penelitian yaitu siswa SMA Kristen Tumou Tou kota Bitung yang berusia 13-18 tahun yang menderita obese dan yang non obese sebagai pembanding.

\section{HASIL PENELITIAN}

Dari penelitian yang telah dilakukan secara acak terhadap 137 orang siswa di SMA Kristen Tumou Tou Kota Bitung dengan mengukur lingkar pinggang. Dipilih 11 orang siswa yang obese kemudian dilakukan pengambilan darah untuk melihat 
428 Jurnal e-Biomedik (eBM), Volume 2, Nomor 2, Juli 2014, hlm. 426-430

kadar asam urat. Dan di peroleh hasil 4 orang siswa yang memiliki kadar asam urat di atas normal.

Dilakukan juga pengambilan darah terhadap 11 orang yang bersedia dan tidak mengalami obesitas sebagai perbandingan.
Dan diperoleh 3 orang yang memiliki kadar asam urat diatas normal.

Tabel 1. Kadar asam urat remaja obese

\begin{tabular}{|c|c|c|c|c|}
\hline $\begin{array}{l}\text { Nama } \\
\text { (thn) }\end{array}$ & $\begin{array}{l}\text { Umur } \\
(\mathrm{L} / \mathrm{P})\end{array}$ & Jenis Kelamin & $\begin{array}{l}\text { Lingkar Pinggang } \\
\text { (cm) }\end{array}$ & $\begin{array}{l}\text { Kadar Asam urat } \\
(\mathrm{mg} / \mathrm{dl})\end{array}$ \\
\hline GM & 16 & $\mathrm{~L}$ & 99 & $* 9,7$ \\
\hline ChP & 14 & $\mathrm{P}$ & 85 & 4,9 \\
\hline SK & 16 & $\mathrm{P}$ & 86 & $* 7,0$ \\
\hline TK & 16 & $\mathrm{P}$ & 83 & 4,1 \\
\hline TW & 16 & $\mathrm{P}$ & 82 & 4,5 \\
\hline $\mathrm{CP}$ & 16 & $\mathrm{P}$ & 81,5 & $* 6,0$ \\
\hline FT & 15 & $\mathrm{P}$ & 81 & 4,3 \\
\hline NR & 16 & $\mathrm{P}$ & 81,5 & 4,7 \\
\hline AS & 16 & $\mathrm{~L}$ & 103 & $* 7,1$ \\
\hline SP & 16 & $\mathrm{P}$ & 85 & 4,5 \\
\hline CT & 16 & $\mathrm{P}$ & 101 & 4,4 \\
\hline
\end{tabular}

Keterangan: $(*)$ melebihi batas normal

Tabel 2. Kadar asam urat pada remaja nonobese

\begin{tabular}{|c|c|c|c|c|}
\hline Nama & $\begin{array}{l}\text { Umur } \\
\text { (thn) }\end{array}$ & $\begin{array}{l}\text { Jenis Kelamin } \\
(\mathrm{L} / \mathrm{P})\end{array}$ & $\begin{array}{l}\text { Lingkar Pinggang } \\
\text { (cm) }\end{array}$ & $\begin{array}{l}\text { Kadar Asam urat } \\
(\mathrm{mg} / \mathrm{dl})\end{array}$ \\
\hline NP & 17 & $\mathrm{~L}$ & 70 & $* 7,8$ \\
\hline SS & 16 & $\mathrm{P}$ & 75 & 4,8 \\
\hline $\mathrm{DD}$ & 17 & $\mathrm{P}$ & 70 & 4,2 \\
\hline FK & 16 & $\mathrm{P}$ & 78,5 & 5,7 \\
\hline SP & 15 & $\mathrm{P}$ & 73 & 5,1 \\
\hline $\mathrm{ZT}$ & 17 & $\mathrm{P}$ & 77 & 5,2 \\
\hline MT & 17 & $\mathrm{P}$ & 74,5 & $* 6,5$ \\
\hline IM & 18 & $\mathrm{P}$ & 67,5 & 4,8 \\
\hline AT & 14 & $\mathrm{P}$ & 69 & 5,3 \\
\hline AM & 15 & $\mathrm{P}$ & 74 & 3,7 \\
\hline GK & 16 & $\mathrm{~L}$ & 65 & $* 6,4$ \\
\hline
\end{tabular}

Keterangan : $(*)$ melebihi batas normal

Statistik hasil penelitian dapat dilihat pada tabel berikut ini. 
Tabel 3. Statistik hasil penelitian

\begin{tabular}{lccccc}
\hline Sampel & $\begin{array}{c}\text { Rata-rata } \\
(\mathrm{mg} / \mathrm{dl})\end{array}$ & $\begin{array}{c}\text { Nilai minimal } \\
(\mathrm{mg} / \mathrm{dl})\end{array}$ & $\begin{array}{c}\text { Nilai maksimal } \\
(\mathrm{mg} / \mathrm{dl})\end{array}$ & $\begin{array}{c}\text { Median } \\
(\mathrm{mg} / \mathrm{dl})\end{array}$ & $\begin{array}{c}\text { Modus } \\
(\mathrm{mg} / \mathrm{dl})\end{array}$ \\
\hline Obese & 5,6 & 4,1 & 9,7 & 4,7 & 4,5 \\
Non obese & 5,4 & 3,7 & 7,8 & 5,2 & 4,8 \\
\hline
\end{tabular}

\section{BAHASAN}

Penelitian dengan menggunakan sampel siswa SMA Kristen Tumou Tou kota Bitung ini dilakukan pada bulan NovemberDesember 2013, awal penelitian peneliti terlebih dahulu membuat surat pengantar penelitian yang disetujui Kepala Dinas Pendidikan Pemuda dan Olahraga Kota Bitung. Kemudian surat tersebut diserahkan kepada Kepala Sekolah SMA Kristen Tumou Tou Kota Bitung untuk mendapatkan izin penelitian. Pada penelitian ini dipilih secara acak terhadap 137 orang siswa SMA Kristen Tumou Tou kota Bitung yang berusia 13-18 tahun dan diperoleh 17 orang siswa termasuk dalam kategori obesitas (12,4\%). Terdapat 4 laki-laki (2,91\%) dan 13 perempuan $(9,5 \%)$.

Dari 17 orang siswa dilakukan pengambilan darah terhadap 11 orang siswa yang telah bersedia untuk dijadikan sampel. Sebagai pembandingnya dilakukan pengambilan sampel terhadap 11 orang siswa yang termasuk dalam kategori non obese. Dari hasil pengambilan darah tersebut diperoleh prevalensi siswa obese yang mengalami hiperurisemia adalah $36,36 \%$ dan pada siswa non obese yang mengalami hiperurisemia 27,27\%.

Faktor-faktor penyebab terjadinya obesitas antara lain genetik, gaya hidup dan faktor lingkungan. Gaya hidup seperti penurunan aktivitas fisik dan pengaturan makan yang tidak baik merupakan penyebab obesitas. $^{7}$

Hasil penelitian prevalensi hiperurisemia pada remaja obese di SMA Kristen Tumou Tou kota Bitung ini berhubungan dengan hasil penelitian yang dilakukan di jepang oleh Oyama dkk. tentang prevalensi hiperurisemia pada remaja yang memiliki persentase kelebihan berat badan adalah $\geq 20 \%$. $^{12}$

Tubuh orang yang mengalami obesitas akan terjadi peningkatan pelepasan jumlah asam lemak bebas ke dalam sirkulasi. Asam lemak bebas merupakan sumber utama energi pada keadaan puasa dan pada keadaan obesitas asam lemak bebas yang masuk ke dalam jaringan melebihi kebutuhan. Masuknya asam lemak bebas yang berlebihan ini ke dalam otot mengakibatkan terjadinya resistensi insulin. ${ }^{13}$

Resistensi insulin, hipoksia dan kematian sel dapat menginduksi perubahan xanthine. Insulin berperan dalam meningkatkan reabsorpsi asam urat di tubuli proksimal ginjal. Sehingga pada keadaan hiperinsulinemia pada pra diabetes terjadi peningkatan reabsorpsi yang akan menyebabkan hiperurisemia. ${ }^{14}$

Tingginya Prevalensi hiperurisemia pada remaja non obese di SMA Kristen Tumou Tou kota Bitung ini diduga adanya beberapa faktor yang berperan antara lain, genetik, alkohol, dan makanan yang tinggi purin. Makanan tinggi purin seperti daging dan seafood. ${ }^{3,15}$

Sesuai letak geografisnya kota Bitung terletak didekat pantai ini memperkuat dugaan kemungkinan penyebab terjadinya hiperurisemia karena mengkonsumsi makanan yang tinggi purin yang berasal dari laut.

Melalui penelitian yang dilakukan di SMA Kristen Tumou Tou kota Bitung ini menunjukan bahwa kehidupan masyarakat kota Bitung mempunyai kebiasaan mengkonsumsi makanan yang tinggi purin yang berasal dari laut, terutama ikan karena kota Bitung terletak didekat pantai. 


\section{SIMPULAN}

Berdasarkan hasil penelitian dapat disimpulkan bahwa prevalensi remaja obese yang mengalami hiperurisemia dikota Bitung adalah 36,36 \%.

\section{SARAN}

Berdasarkan hasil penelitian, penulis menyarankan kepada remaja untuk dapat mengatur pola makan dan memperbanyak aktivitas fisik, amat terlebih bagi remaja yang obese, karena dengan ukuran berat badan yang lebih memiliki kecencerungan timbulnya berbagai macam penyakit. Juga kepada orang tua untuk dapat membantu anak dalam mengatur pola hidup sehat dan mengontrol kadar asam urat secara berkala guna menghindari komplikasi yang lebih serius. Serta penulis menyarankan perlu dilakukan penelitian lebih lanjut tentang prevalensi hiperurisemia pada remaja obese agar supaya diperoleh hasil yang lebih jelas.

\section{DAFTAR PUSTAKA}

1. Akram M, Asif HM, Usmanghani $\mathrm{K}$, Akhtar N, Jabeen Q, Madni A, et all. Obesity and risk of hiperurisemia in gadap town, Karachi. African Journal; Februari 2011. Available from: http://www.acadeic journals.org/ajb/PDF/pdf2011/7Feb/Akram \%20et\%20al.pdf. Di unduh 14 September 2013. Hal 996-98.

2. AL-Hamdani IH. Estimation of Serum Uric Acid, Urea and Creatinine in Essential Hypertensive Patients. Tikrit medical journal; 2010; 16(1). Available from: http://www.iasj.net/iasj?func=fulltext\&ald= 22036

3. Misnadiarly. Rematik. Edisi I, Jakarta: Pustaka Obor Populer; September 2007.

4. Putra TR. Hiperurisemia. Dalam Buku Ajar Ilmu Penyakit Dalam, Jilid III Edisi ke-V, Jakarta: Departemen Ilmu Penyakit Dalam fakultas Kedokteran Universitas Indonesia; 2009. Hal 2550-50.

5. Sugondo S. Obesitas. Dalam Buku ajar Ilmu Penyakit Dalam. Jilid III Edisi ke-V. Jakarta: Departemen Ilmu Penyakit Dalam fakultas Kedokteran Universitas Indonesia; 2009. Hal 1973-83.

6. The International Diabetes Federation (IDF) concencus worldwide definition of the metabolic syndrome. Di unduh 31 Januari 2013.

7. Guyton AC, Hall JE. Textbook of Medical Physiology. Terjemahan Bahasa Indonesia ECG, $11^{\text {th }}$ Ed, Philadelphia Elsevier Saunders ; 2007. ejournal. Hal 917 - 18.

8. Ranti GC, Fatimawali, Wehantouw F. Uji efektivitas ekstrak flavonoid dan steroid dari gedi (abelmoschus manihot) sebagai anti obesitas dan hipolipidemik pada tikus putih jantan galur wistar. Pharmacon jurnal ilmiah farmasi - Unsrat; Mei; 2013. Vol 2. Available from: http://ejournal.unsrat.ac. id/index.php/pharmacon/article/download/1 554/1247. Di unduh: 27 September 2013.

9. Mulyadi CK, Fransiska, Pramudya KM, Kevin, Lenardi M, Sukmaniah S. Hubungan antopometri, aktivitas fisik dan pengetahuan gizi dengan asupan energi dan kmposisi makronutrien pada remaja. eJKI ;Agustus 2013. Vol. 1

10. Laporan hasil Riset Kesehatan Dasar (RISKESDAS) 2013. Badan Penelitian dan Pengembangan Kesehatan. Diunduh : 4 Februari 2014.

11. Bonde JY. Prevalensi hiperurisemia pada remaja obesitas di SMA Negeri 1 Kota Bitung [skripsi]. Fakultas Kedokteran Universitas Sam Ratulangi; 2011

12. Oyama $\mathrm{C}$, Takahashi $\mathrm{T}$, Oyama $\mathrm{M}$, Oyamada T, Ohno T, Mayashita M, et al. Serum uric acid as an obesity telated indicator in early adolescence. Tohoku J. Exp.Med ; 2006 ; 209, 257 - 262.

13. Karimba A, Kaligis S, Purwanto D. Gambaran Kadar Asam Urat Pada Mahasiswa Angkatan 2011 Fakultas Kedokteran Universitas Samratulangi dengan IMT $\geq 23 \mathrm{~kg} / \mathrm{m}^{2}$. Jurnal e-biomedik; Maret 2013. Vol.1.

14. Nasrul E, Sofitri, Hiperurisemia pada Pra Diabetes, Jurnal Kesehatan Andalas 2012. Available from: http://www.jurnal.fk.unand.ac.id/articles/vo l_1no_2/86-91.pdf. Hal 86-91

15. Manampiring Aaltje, Bodhy W. Prevalensi hiperurisemia pada remaja obese di kota Tomohon;2010. 